CARDOSO, AII; MAGRO, FO; OLIVEIRA JÚNIOR, MXO; ABRAHÃO, C; TAVARES, AEB; FERNANDES, DM. 2017. Accumulation of macronutrients in beetroot plant. Horticultura Brasileira 35: 000-000. DOI - http://dx.doi.org/10.1590/S0102-05362017030?

\title{
Accumulation of macronutrients in beetroot plant
}

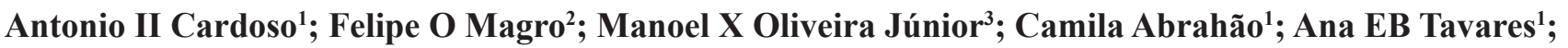 \\ Dirceu M Fernandes ${ }^{1}$ \\ ${ }^{1}$ Universidade Estadual Paulista (UNESP), Botucatu-SP, Brasil; ismaeldh@fca.unesp.br; anaemiliatavares@yahoo.com.br; dmfer- \\ nandes@fca.unesp.br; caabrahao99@gmail.com; ${ }^{2}$ Secretaria de Agricultura, Abastecimento e Turismo de Jundiaí, Jundiaí-SP, Brasil; \\ felipe_magro@yahoo.com.br; ${ }^{3}$ Instituto Federal do Norte de Minas Gerais (IFNMG), Arinos-MG, Brasil; manoelxjr@yahoo.com.br
}

\begin{abstract}
Nutrient need in each development stage of plant is showed by nutrient accumulation curve; this is an important tool for fertilization recommendation. However, researches on vegetables with the objective to estimate these curves are scarce, mainly in the modern hybrids that show higher productivity potential and, probably, higher nutrient demand. In this study, the authors aimed to determine macronutrient accumulation of beetroot plants, hybrid Boro. The experiment was carried out in São Manuel, São Paulo State, Brazil. Five treatments [seasons of plant collection: 0, 14, 28, 43 and 60 days after transplanting (DAT)], considering that in each season 16 plants were collected (four replications of four plants each, in a randomized block design). We evaluated dry matter accumulation, and nitrogen $(\mathrm{N})$, phosphorus $(\mathrm{P})$, potassium $(\mathrm{K})$, calcium $(\mathrm{Ca})$, magnesium $(\mathrm{Mg})$ and sulphur $(\mathrm{S})$ in plant shoot and root. The period of the highest demand for most of macronutrients was from 29 to 43 DAT. The decreasing order of macronutrients exported by the roots of the beetroot was $\mathrm{K}>\mathrm{N}>\mathrm{P}>\mathrm{Mg}>\mathrm{S}>\mathrm{Ca}(376,232,45,29,21$ and 13 $\mathrm{mg} /$ plant, respectively), and accumulated by the whole plant (shoot + root) was $\mathrm{K}>\mathrm{N}>\mathrm{Mg}>\mathrm{Ca}>\mathrm{P}>\mathrm{S}(709,404,126,113,69$ and $50 \mathrm{mg} /$ plant, respectively).
\end{abstract}

Keywords: Beta vulgaris, fertilization, nutrients absorption, nutritional demand.

\section{RESUMO}

\section{Acúmulo de macronutrientes pela beterraba}

A necessidade de nutrientes em cada etapa de desenvolvimento da planta é mostrada pela curva de acúmulo de nutrientes, sendo importante ferramenta para a recomendação de adubação. No entanto, são raras as pesquisas com hortaliças com o objetivo de se obter estas curvas, principalmente nos modernos híbridos que apresentam maior potencial produtivo e, provavelmente, maior necessidade de nutrientes. Objetivou-se com este trabalho determinar o acúmulo de macronutrientes pela planta de beterraba, híbrido Boro. $\mathrm{O}$ experimento foi conduzido em São Manuel-SP. Foram cinco tratamentos [épocas de coleta das plantas: $0,14,28,43$ e 60 dias após o transplante (DAT)], sendo em cada época coletadas 16 plantas (quatro repetições de quatro plantas cada, no delineamento em blocos ao acaso). Foram avaliados o acúmulo da massa seca e de nitrogênio $(\mathrm{N})$, fósforo $(\mathrm{P})$, potássio $(\mathrm{K})$, cálcio $(\mathrm{Ca})$, magnésio $(\mathrm{Mg})$ e enxofre (S) na parte aérea e nas raízes das plantas. O período de maior demanda para a maioria dos macronutrientes foi dos 29 aos 43 DAT. A ordem decrescente dos macronutrientes exportados pelas raízes de beterraba foi $\mathrm{K}>\mathrm{N}>\mathrm{P}>\mathrm{Mg}>\mathrm{S}>\mathrm{Ca}$, com 376, 232, 45, 29, 21 e 13 $\mathrm{mg} /$ planta, respectivamente, e acumulados pela planta (parte aérea + raiz) foi $\mathrm{K}>\mathrm{N}>\mathrm{Mg}>\mathrm{Ca}>\mathrm{P}>\mathrm{S}$, com 709, 404, 126, 113, 69 e $50 \mathrm{mg} /$ planta, respectivamente.

Palavras-chave: Beta vulgaris, adubação, marcha de absorção de nutrientes, demanda nutricional.

\section{Received on December 8, 2015; accepted on July 29, 2016}

$\mathrm{N}$ utrient accumulation curves show the need for nutrients at each stage of plant development, being important for fertilizer recommendation. However, the need for nutrients depends on, among other factors, productivity, environmental conditions and on the cultivar or the hybrid used. Moreover, the authors highlight that the curves reflect what the plant needs, and not what should be applied directly, since the efficiency of nutrients use, which is variable according to weather conditions, soil, irrigation system, cultural management, the nutrient used, among other factors, should be considered. However, this information is still limited, mainly in vegetables (Fonseca et al., 2009; Kano et al., 2011), which are different concerning nutrient requirements and absorption for growth. Generally, phosphorus, nitrogen and potassium absorption follows the same pattern as the rate of plant biomass accumulation.

Like other vegetables, beet is very demanding crop, in relation to nutrients, due to its fast development, showing short vegetative cycle, intensive dry matter production and great nutrient extraction and export. Studies on nutrient uptake rate and dry matter accumulation throughout this vegetable cycle are scarce, though. For beet propagated through seedlings and for modern hybrids, information is even scarcer. Haag \& Minami (1987), working with cultivar Early Wonder, verified an increase in dry matter in plant roots and aboveground part until the end of the crop cycle [ 80 days after sowing date (DAS)] and observed that nutrient extraction was continuous from 40 days until harvesting, increasing at $60 \mathrm{DAS}$.

Grangeiro et al. (2007), also working with cultivar Early Wonder, verified on a population of 333,000 plants/ ha and productivity of $30 \mathrm{t} / \mathrm{ha}$, that 
phosphorus and potassium accumulated preferentially in the roots, whereas nitrogen, calcium and magnesium in the aboveground area, considering that the decreasing order of the nutrients accumulated by the plant was: $\mathrm{N}>\mathrm{K}>\mathrm{Mg}>\mathrm{Ca}>\mathrm{P}$. In the roots, the total amount of $\mathrm{N}, \mathrm{P}, \mathrm{K}, \mathrm{Ca}$ and $\mathrm{Mg}$ exported were $88 ; 6.1 ; 93.2 ; 12.1$ and $16.8 \mathrm{~kg} / \mathrm{ha}$, respectively. Sediyama et al. (2011), evaluating the same cultivar, verified that, for a population of 400,000 plants/ ha and average productivity of $34.22 \mathrm{t} /$ ha, the amount of $\mathrm{N}, \mathrm{P}, \mathrm{K}, \mathrm{Ca}, \mathrm{Mg}$ and $\mathrm{S}$ exported by the roots were $140 ; 24$; $180 ; 8 ; 17$ and $5 \mathrm{~kg} / \mathrm{ha}$, respectively.

Despite the existence of studies in Brazil in which nutrient accumulation was evaluated by the beet plant, all were made with the cultivar Early Wonder. Nonetheless, each year the area, in which hybrids were planted, has been increasing in Brazil (Cardoso, 2013), without researches on nutritional demands, though.

Thus, the authors aimed to obtain the curve of macronutrients accumulated in beet plant (root and aboveground part), hybrid Boro, throughout the cycle.

\section{MATERIAL AND METHODS}

The experiment was carried out at Fazenda Experimental São Manuel, located in the municipality of São Manuel, São Paulo State, Brazil, belonging to Faculdade de Ciências Agronômicas of Universidade Estadual Paulista, Botucatu (2246' S, 48 $34^{\circ}$ 'W, altitude $740 \mathrm{~m}$ ). The local climate is Cfa type, according to Köppen classification, based on weather observations (Mesothermal Temperate Climate) (Cunha \& Martins, 2009). Throughout the experiment, average daily temperature ranged from 15 to $27^{\circ} \mathrm{C}$.

The soil in which the experiment was installed is a typic distrophic Red Latosol, sandy, with about 836, 116 and $48 \mathrm{~g} / \mathrm{kg}$ of sand, silt and clay, respectively. The chemical analysis showed: $\mathrm{pH}_{(\mathrm{CaCl} 2)}=6.3$; organic matter $=$ $10 \mathrm{~g} / \mathrm{dm}^{3} ; \mathrm{H}^{+}+\mathrm{Al}^{3+}=13 \mathrm{mmol} / \mathrm{dm}^{3} ; \mathrm{K}^{+}=$ $1.4 \mathrm{mmol} / \mathrm{dm}^{3} ; \mathrm{P}_{\text {resin }}=22 \mathrm{~g} / \mathrm{dm}^{3} ; \mathrm{Ca}^{2+}=$ $36 \mathrm{mmol}_{\mathrm{c}} / \mathrm{dm}^{3} ; \mathrm{Mg}^{2+}=15 \mathrm{mmol} / \mathrm{dm}^{3}$;
$\mathrm{SB}=52 \mathrm{mmol} / \mathrm{dm}^{3} ; \mathrm{CTC}=65 \mathrm{mmol}_{\mathrm{c}} /$ $\mathrm{dm}^{3}$ and $\mathrm{V}=80 \%$.

Fertilization at planting was carried out in the total area of the seedbed, incorporating organic and inorganic fertilizers into 20-cm-depth soil, on $08 / 25 / 2010$. The authors applied $60 \mathrm{~kg} /$ ha of organic compound, into a wet base, $250 \mathrm{~kg} /$ ha of formulated 8-28-16, 230 $\mathrm{kg} / \mathrm{ha}$ of potassium chloride and 1600 $\mathrm{kg} / \mathrm{ha}$ of magnesian thermophosphate to meet the requirement of nitrogen, phosphorus and potassium, suggested by Trani \& Raij (1997) which is 20, 360 and $180 \mathrm{~kg} / \mathrm{ha}$ of $\mathrm{N}, \mathrm{P}_{2} \mathrm{O}_{5}$ and $\mathrm{K}_{2} \mathrm{O}$, respectively. In the top dressing fertilization, the authors applied $90 \mathrm{~kg} /$ ha of $\mathrm{N}$, in the form of urea, divided into three times, at intervals of 14 days after transplanting.

The chemical analysis of the organic compound showed values of $\mathrm{MO} ; \mathrm{N}$; $\mathrm{P}_{2} \mathrm{O}_{5} ; \mathrm{K}_{2} \mathrm{O} ; \mathrm{Ca} ; \mathrm{Mg}$ and $\mathrm{S}$, expressed in $\%$ of dry matter, respectively of: $41 ; 0.72 ; 0.39 ; 0.30 ; 2.70 ; 0.30$ and 0.19 . The $\mathrm{C} / \mathrm{N}$ ratio was of 32 and the moisture content of the compound of $37.9 \%$.

The authors used hybrid $\mathrm{F}_{1}$ Boro from Bejo ${ }^{\circledR}$ company. Sowing was carried out on $07 / 29 / 2010$, in expanded polystyrene trays of 288 cells, containing commercial substrate for vegetable production. Seedlings were transplanted on 08/30/2010 into 1.20-meter-length seedbeds, totaling four lines longitudinally, spacing 0.25 $\mathrm{m}$ between lines and $0.125 \mathrm{~m}$ between plants. The weed control was carried out through manual hoeing throughout the crop cycle. The authors used sprinkler irrigation system.

Five plant samplings were carried out $[0,14,28,43$ and 60 days after transplanting date (DAT)], being collected 16 plants (four replications of four plants each, in a randomized block design) on each day. The authors considered 0 (zero) the day of the seedling transplanting, when the first sampling was collected (16 seedlings). From the third collection on (28 DAT) the plants were divided into two samplings: shoot and root. In the field, after the transplanting, the end rows were considered border rows, as well as all the neighboring plants to the collected plants.

After being collected, the samples were taken to the laboratory and properly washed and, after removing the excess of water, the shoot samples were packed in paper bags, identified and taken to be dried in forced air circulation at $65^{\circ} \mathrm{C}$, until they reached constant mass, according to Malavolta et al. (1997). Afterwards, using an analytical balance, the authors obtained dry matter mass of each sample. In relation to the roots, the samples remained for 48 hours in forced air circulation at $65^{\circ} \mathrm{C}$. Then, the material was thinly sliced and, again, put in forced air circulation at $65^{\circ} \mathrm{C}$ for 72 hours. Afterwards, using an analytical balance, the authors obtained dry matter mass of each sample.

After drying, each sample passed through a grinder using a Willey type mill. Sulfuric acid digestion was used to obtain the extract for determining N. Nitric-perchloric digestion was used to obtain extracts to determine the other macronutrients $(\mathrm{P}, \mathrm{K}, \mathrm{Ca}, \mathrm{Mg}$ and $\mathrm{S}$ ), according to the methodologies presented by Malavolta et al. (1997).

Based on the chemical analyses, the authors obtained contents of $\mathrm{N}, \mathrm{P}, \mathrm{K}$, $\mathrm{Ca}, \mathrm{Mg}$ and $\mathrm{S}$, and then, the contents were multiplied by the mass of the dry matter of the sample in order to obtain the accumulated amount.

Data of accumulation of dry matter and macronutrients in the aboveground part, root and whole plant (aboveground part + root), throughout the period evaluated, were adjusted to the nonlinear equation which produces a sigmoidal curve (Boltzmann function), using the software SigmaPlot 11.0, according to the following equation:

$$
\mathrm{y}=\frac{a}{1+e^{-\left(\frac{x-x o}{b}\right)}}
$$

in which $\mathrm{x}=$ days after transplanting.

\section{RESULTS AND DISCUSSION}

Plant growth was slow until 28 DAT (Figure 1). Until this evaluation, dry matter was constituted almost exclusively by the aboveground part. In the evaluation carried out at 43 DAT, 
the root dry matter almost equaled that of the aboveground part dry matter, surpassing it right after this evaluation.

The highest aboveground part dry matter accumulation occurred from 28 to 43 DAT, decreasing considerably after 43 DAT until the harvest (Figure 1). The highest dry matter accumulation of the root and the whole plant occurred from 43 to 60 DAT. Grangeiro et al. (2007) also reported that the highest aboveground part accumulation occurred before the highest root demand.

Both, in this study and in the study carried out by Grangeiro et al. (2007), the authors verified that the aboveground part accumulation rate throughout the cycle decreased at the end of the cycle, whereas the root accumulation rate increased (Figure 1).

Table 1. Parameters of nonlinear equation for the dry matter mass (mg/plant) and amount of accumulated macronutrients (mg/plant) in the shoot, root and whole beetroot plant. São Manuel, UNESP, 2010.

\begin{tabular}{|c|c|c|c|c|}
\hline & $\mathbf{a}$ & b & $\mathbf{x}_{0}$ & $\mathbf{R}^{2}$ \\
\hline \multicolumn{5}{|l|}{ Dry matter mass } \\
\hline Shoot & 6,07 & 5,86 & 31,47 & 0,9999 \\
\hline Root & 16,44 & 6,47 & 49,78 & 1,0000 \\
\hline Total & 23,72 & 8,68 & 46,32 & 0,9995 \\
\hline Macronutrients & \multicolumn{4}{|c|}{ Shoot } \\
\hline Nitrogen & 177,28 & 5,96 & 26,81 & 0,9972 \\
\hline Phosphorus & 25,91 & 5,56 & 29,26 & 0,9845 \\
\hline Potassium & 341,92 & 5,53 & 29,89 & 0,9956 \\
\hline Calcium & 121,86 & 10,53 & 44,21 & 0,9994 \\
\hline Magnesium & 100,93 & 7,74 & 32,77 & 0,9997 \\
\hline \multirow[t]{2}{*}{ Sulphur } & 29,26 & 5,42 & 34,23 & 0,9984 \\
\hline & \multicolumn{4}{|c|}{ Root } \\
\hline Nitrogen & 481,81 & 11,09 & 60,81 & 1,0000 \\
\hline Phosphorus & 58,50 & 8,25 & 50,29 & 1,0000 \\
\hline Potassium & 519,16 & 9,51 & 50,86 & 1,0000 \\
\hline Calcium & 122,57 & 15,45 & 93,11 & 1,0000 \\
\hline Magnesium & 72,45 & 10,49 & 64,50 & 1,0000 \\
\hline \multirow[t]{2}{*}{ Sulphur } & 28,27 & 8,01 & 51,43 & 1,0000 \\
\hline & \multicolumn{4}{|c|}{ Whole plant } \\
\hline Nitrogen & 466,84 & 10,46 & 40,77 & 0,9967 \\
\hline Phosphorus & 77,78 & 8,89 & 41,29 & 1,0000 \\
\hline Potassium & 762,46 & 8,46 & 38,35 & 0,9997 \\
\hline Calcium & 143,96 & 10,77 & 45,96 & 0,9993 \\
\hline Magnesium & 137,37 & 9,19 & 37,51 & 0,9989 \\
\hline Sulphur & 53,08 & 7,19 & 40,07 & 0,9999 \\
\hline
\end{tabular}

$\mathrm{R}^{2}=$ determination coefficient.

Equation: $\mathrm{Y}=$, where $\mathrm{x}=$ days after transplanting.
Guimarães et al. (2002) verified a large initial investment in the aboveground part for the establishment of organs responsible for the source of assimilated nutrients. Stabilization of dry matter accumulation in the aboveground part coincides with the accumulation of dry matter in the roots, which is a reserve organ and also becomes the main drain of the plant. For these authors, the dry matter in the roots reached almost twice the aboveground part dry matter, at the end of the evaluation (98 DAS). Similar results were observed by Nunes et al. (1981) in sugar beetroot. Also, in this study, the root dry matter at the end of the cycle was approximately twice the aboveground dry matter (Figure 1), considering that dry matter accumulation was approximately $20 \mathrm{~g} /$ plant, similar value to the one obtained by Grangeiro et al. (2007), of $21 \mathrm{~g} /$ plant.

The amount of N, P, K, Ca, Mg and $\mathrm{S}$ accumulated in the aboveground part, root and whole plant (Figure 2, Table 1) throughout the beetroot cycle showed a similar trend concerning dry matter accumulation and it was adjusted to the sigmoidal equation.

Most macronutrients had higher accumulation values in the above ground part from 29 to 43 DAT, except for nitrogen and calcium, which showed period of highest demand from 15 to 28 and from 44 to $60 \mathrm{DAT}$, respectively (Table 2). In the study carried out by Grangeiro et al. (2007), with exception for potassium, which had the highest demand from 30 to $40 \mathrm{DAS}$, the period of the highest demand for the other macronutrients occurred from 40 to 50 DAS, which was also the penultimate evaluation period throughout the cycle. Those authors mentioned used direct sowing, whereas in this study, we used indirect sowing, with production and seedling transplanting.

Until 43 DAT, the average daily accumulation increased in the aboveground part of the beetroot, considering that, after this period, the accumulation rate decreased, being close to zero of $\mathrm{N}$ and $\mathrm{P}$ (Table 2). One explanation for the decreasing trend in accumulation rate in the final phase is that from 43 DAT, an inversion among the plant drains, with nutrients 
Table 2. Average daily accumulation of macronutrients (mg/plant/day), in each interval between collections, for the shoot, root and whole beetroot plant. São Manuel, UNESP, 2010.

\begin{tabular}{lcccccc}
\hline Period & N & P & K & Ca & Mg & S \\
\hline \multicolumn{7}{c}{ Shoot } \\
\hline 0 a 14 & 1,50 & 0,22 & 2,27 & 0,37 & 0,54 & 0,11 \\
15 a 28 & 5,59 & 0,55 & 7,86 & 1,26 & 2,15 & 0,39 \\
29 a 43 & 5,51 & 1,06 & 13,37 & 2,47 & 3,10 & 1,27 \\
44 a 60 & 0,02 & $-0,05$ & 0,64 & 2,67 & 1,19 & 0,27 \\
\hline \multicolumn{7}{c}{ Root } \\
\hline 29 a 43 & 4,05 & 0,96 & 8,21 & 0,20 & 0,44 & 0,42 \\
44 a 60 & 9,47 & 1,73 & 13,60 & 0,52 & 1,27 & 0,86 \\
\hline \multicolumn{7}{c}{ Whole plant } \\
\hline 0 a 14 & 1,50 & 0,22 & 2,27 & 0,37 & 0,54 & 0,11 \\
15 a 28 & 5,59 & 0,55 & 7,86 & 1,26 & 2,15 & 0,39 \\
29 a 43 & 9,57 & 2,02 & 21,58 & 2,67 & 3,54 & 1,69 \\
44 a 60 & 9,49 & 1,67 & 14,24 & 3,18 & 2,45 & 1,13 \\
\hline
\end{tabular}

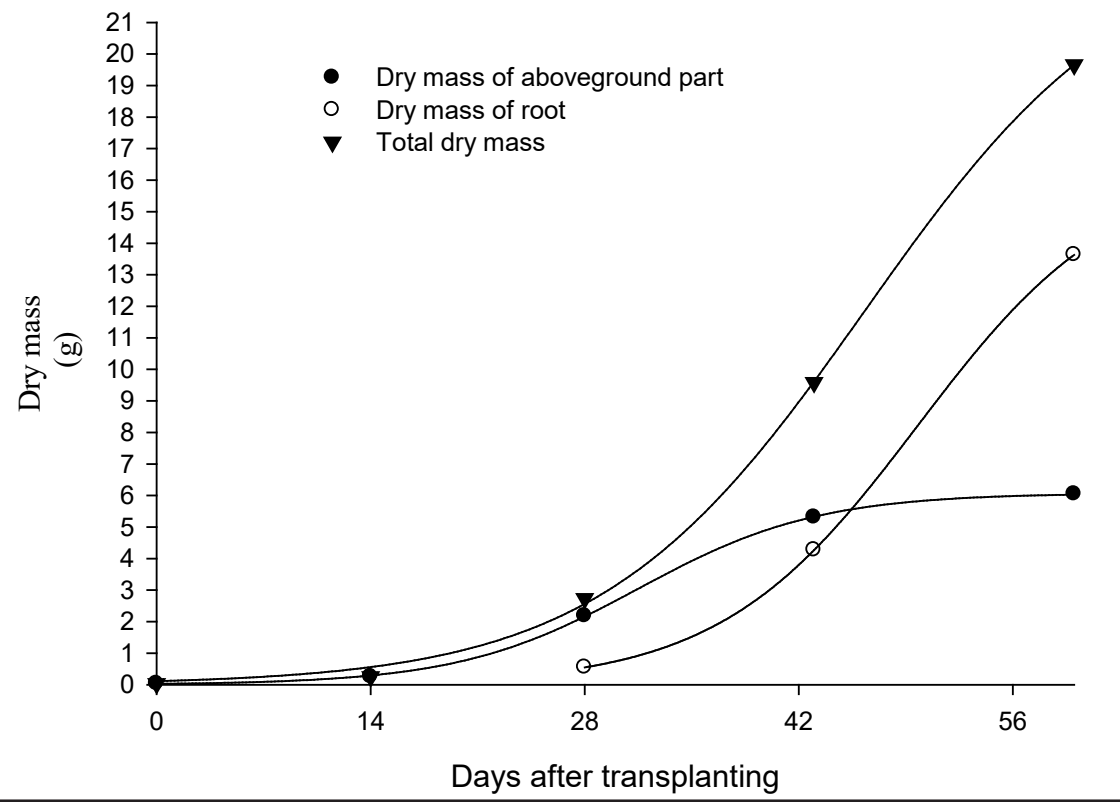

Figure 1. Dry matter mass accumulated by shoot, root and whole plant throughout the crop cycle. São Manuel, UNESP, 2010.

being translocated to the roots was noticed. Except for the calcium, which accumulation in the aboveground part increased in the last period; this can be explained by the low mobility of this nutrient in the plant. According to Malavolta (2006), low accumulation of $\mathrm{Ca}$ in the reserve organs, such as fruits, tubers and tuberous roots, is due to low mobility of this nutrient in plant; thus, this nutrient is retained in the stems and leaves and it is not directed
The authors highlight $\mathrm{K}$ as the most accumulated nutrient, showing an amount much more superior to the second nutrient $(\mathrm{N})$.

In relation to the roots, for all macronutrients, the highest accumulation rate occurred at the end of the cycle, from 44 to 60 days (Table 2). In the study carried out by Grangeiro et al. (2007), the period of the highest accumulation for all macronutrients in the roots also coincided with the last period, between 50 and 60 DAS.

The decreasing order of accumulated macronutrients (exported) by beet roots was $\mathrm{K}>\mathrm{N}>\mathrm{P}>\mathrm{Mg}>\mathrm{S}>\mathrm{Ca}$, showing 376, 232, 45, 29, 21 and $13 \mathrm{mg} / \mathrm{plant,}$ respectively (Figure 2).

Calcium and phosphorus show great differences in relation to their accumulation in plant organs. Calcium was the least accumulated nutrient in roots, whereas it was the third most accumulated nutrient in the aboveground part, probably due to low mobility of this nutrient in plant and its accumulation in leaves throughout the cycle via transpiration flow (Malavolta, 2006). Being the second least accumulated nutrient in the aboveground part, phosphorus was the third most accumulated nutrient in the roots. Similar results were observed by Alves et al. (2008), which explained that the higher P requirement in tuberous root is due to its function, which is to promote a fast and continuous growth of this organ. Sediyama et al. (2011) obtained the following decreasing order of accumulated macronutrients (exported) by the roots: $\mathrm{K}>\mathrm{N}>\mathrm{Ca}>\mathrm{Mg}>\mathrm{P}>\mathrm{S}$, whereas Grangeiro et al. (2007) obtained the following order: $\mathrm{K}>\mathrm{N}>\mathrm{Mg}>\mathrm{Ca}>\mathrm{P}$. The main difference between the order found in those studies and in this study is the macronutrient phosphorus. In this study, $\mathrm{P}$ was the third most accumulated macronutrient in the roots, showing that, probably, in the evaluated hybrid, phosphorus is more concentrated in the roots and, consequently, more exported, being necessary higher amount of this nutrient in this hybrid than in cultivar Early Wonder, used by all the other authors mentioned.

The amounts of nutrients exported 


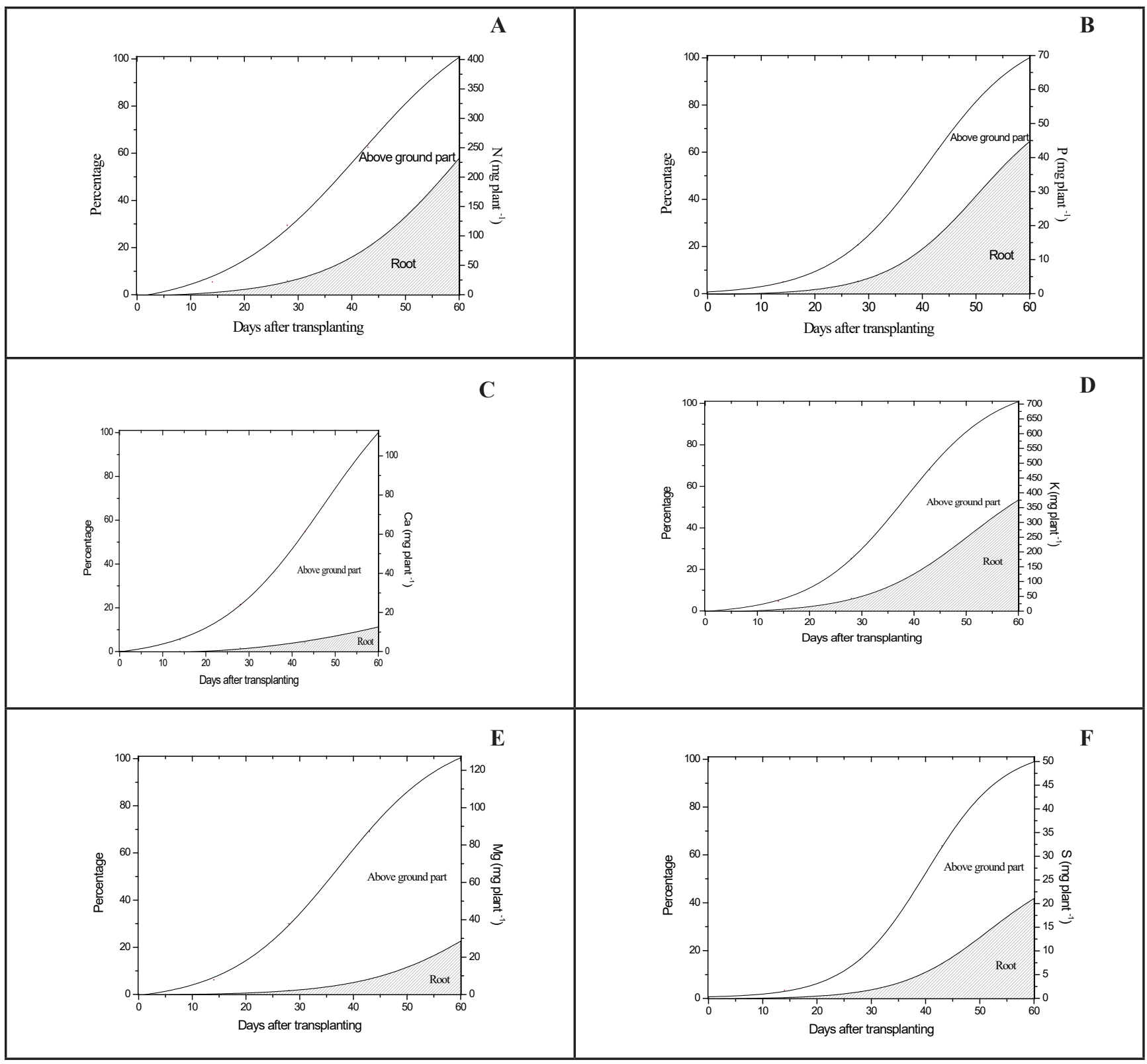

Figure 2. Amount of macronutrient (mg/plant) accumulated by shoot and root in beetroot plant throughout the crop cycle and percentage in relation to the total accumulated at the end of cycle. São Manuel, UNESP, 2010.

by the roots represent an important component of soil nutrient loss, which should be returned. The nutrients contained in the aboveground part can be incorporated into the soil within a program of reclaiming cultural remains (Grangeiro et al., 2007).

When evaluating the whole plant (aboveground part + root), the authors observed that the highest demand of macronutrients occurred from 29 to 43 DAT, except for calcium which this demand was in the final period from 44 to 60 DAT (Table 2). In this period, average accumulation rate of nitrogen was $9.57 \mathrm{mg} / \mathrm{plant} /$ day, very close to the last period, from 44 to 60 DAT, which was $9.49 \mathrm{mg} / \mathrm{plant} /$ day. The total accumulation of nitrogen in beetroot in the end of the cycle, at 60 DAT, reached $404.33 \mathrm{mg} /$ plant (Figure 2). Also on harvest date (60 DAS), Grangeiro et al. (2007) verified that the total accumulation of nitrogen in cultivar Early Wonder was $558.3 \mathrm{mg} /$ plant, it means, little higher than the one found in this study.

Phosphorus was the second least accumulated nutrient in beetroot, 69.34 $\mathrm{mg} /$ plant, reached at 60 DAT (Figure
$2)$. The approximate accumulation rate in the period of greatest demand, from 29 to 43 DAT, was $2.02 \mathrm{mg} / \mathrm{plant} /$ day (Table 2). The results obtained by Grangeiro et al. (2007) were lower, with accumulation, at the end of the cycle at $60 \mathrm{DAS}, 30.67 \mathrm{mg} / \mathrm{day}$, and maximum accumulation rate was approximately $0.84 \mathrm{mg} / \mathrm{plant} / \mathrm{day}$, it means, less than half values obtained in this research, confirming the highest demand for phosphorus in evaluated hybrid.

Potassium was the most accumulated macronutrient, showing, at 60 DAT, $708.52 \mathrm{mg} /$ plant (Figure 2); the highest 
demand occurred in the period from 29 to 43 DAT, and the average daily accumulation rates of $\mathrm{K}$ was $21.58 \mathrm{mg} /$ plant/day (Table 2). In the study carried out by Grangeiro et al. (2007), potassium was the second most accumulated nutrient in cultivar Early Wonder, considering the highest demand from 30 to $40 \mathrm{DAS}$, and showing the maximum accumulation of $538 \mathrm{mg} / \mathrm{plant} /$ day at 60 DAS, a much lower value than the one obtained in this study.

The total calcium accumulation was $112.56 \mathrm{mg} / \mathrm{plant}$ reached at 60 DAT (Figure 2). The highest demand $(3.18 \mathrm{mg} /$ plant/day) was from 44 to 60 DAT (Table 2), coinciding with the greatest dry matter accumulation in the plant. The result is similar to the study carried out by Grangeiro et al. (2007), in which the authors verified the maximum accumulation of calcium of $110.24 \mathrm{mg} /$ plant, at 60 DAS reaching the greatest demand from 40 to 50 DAS, also coinciding with the greatest dry matter accumulation in plant.

The total magnesium accumulated in plant was $126.81 \mathrm{mg} /$ plant, reached at 60 DAT (Figure 2), with the highest demand from 29 to 43 DAT (Table 2). The accumulation rate within this interval was approximately $3.54 \mathrm{mg} /$ plant/day. In the study carried out by Grangeiro et al. (2007), the total magnesium accumulated in plant was $253.37 \mathrm{mg} /$ plant, it means twice the value found in this study, with the highest demand from 50 to 60 DAS , coinciding with the largest increase of the dry matter in plant.

Sulphur was the least accumulated macronutrient in beetroot, $49.95 \mathrm{mg} /$ plant, reached at 60 DAT (Figure 2). The highest demand was from 29 to 43 DAT (Table 2), showing average daily accumulation rate of $1.69 \mathrm{mg} / \mathrm{plant} /$ day.

The decreasing order of accumulated macronutrients in beetroot was $\mathrm{K}>\mathrm{N}>\mathrm{Mg}>\mathrm{Ca}>\mathrm{P}>\mathrm{S}$. The authors highlight the phosphorus which was only the penultimate macronutrient in total accumulated in plant. Similar result was observed by Grangeiro et al. (2007), which observed that phosphorus was the least accumulated nutrient in beetroot. However, sulphur was not evaluated by the mentioned authors. In spite of the great importance of phosphorus for the good development of the root, according to Alves et al. (2008), and being the most recommended nutrient in planting fertilization by Trani \& Raij (1997), the efficiency of phosphorus use is very low, due to the high fixation of this nutrient in the soil.

In relation to percentage distribution of macronutrients in plant organs (aboveground part and root), for nitrogen, the authors observed that about $57.4 \%$ were accumulated in the roots at the end of the cycle (Figure 2). The authors verified a decrease in the percentage of $\mathrm{N}$ accumulation in the aboveground area, and an increase in accumulation in the roots, throughout the cycle, which, according to Grangeiro et al. (2007), show an inversion in relation to the preferential drains for the plant, besides the redistribution for being a mobile nutrient.

Potassium accumulation at the end of the cycle prevailed in the root, $53 \%$ of the total accumulation, against $47 \%$ of the aboveground area (Figure 2), values which are almost the same to the ones verified by Grangeiro et al. (2007): 48 and $52 \%$, in the root and above ground part, respectively.

Phosphorus was accumulated, most of the part, in the roots $(64.5 \%)$ in comparison to the aboveground part at the end of the cycle (Figure 2). The results are close to the ones obtained by Grangeiro et al. (2007), which showed participation of root in 59.3\% of the total P accumulated, whereas the above ground area contributed $40.7 \%$. Phosphorus, nitrogen and potassium were the nutrients which accumulation prevailed in the root in relation to the aboveground area at the end of the cycle.

The authors observed difference in the percentage distribution of $\mathrm{Ca}$ between the aboveground area and the root, 88.6 and $11.4 \%$, respectively. Grangeiro et al. (2007) also observed predominance of $\mathrm{Ca}$ accumulation in beetroot aboveground part, about $67.1 \%$ of total, although the values were different from those found in this study ( $88.6 \%$ in the aboveground part, Figure 2 ). This result, the highest accumulation in the aboveground part was also noticed in potato, which is also a reserve organ
(Fernandes et al., 2011).

For the magnesium accumulation, contributions of the aboveground part and roots at the end of the cycle were 77.5 and $22.5 \%$, respectively (Figure 2). In the study carried out by Grangeiro et al. (2007), participation of the aboveground part and roots in this nutrient accumulation was 80 and $20 \%$. According to the authors, magnesium, in greater amounts than calcium, accumulated preferentially in the aboveground part since it is part of chlorophyll molecule. However, in this study, the authors observed higher proportion of $\mathrm{Ca}$ in the aboveground part than the proportion of Mg. For S accumulation, the aboveground part participated with $57.9 \%$ of the total accumulated at the end of the cycle, whereas the roots contributed to $42.1 \%$.

The percentage distribution of nutrients in each organ of the plant (aboveground part and root) in relation to total is directly related to the mobility of these nutrients in plants and to the necessity of each nutrient in each part of the plant. Mobility can be well observed in calcium, with great percentage accumulation in the aboveground part (88.6\%, Figure 2), even with twice the accumulation of dry matter in the root in relation to the aboveground part (Figure 1). Phosphorus, besides great mobility in the plant, according to Alves et al. (2008), is of great importance for the development of the root, being the most accumulated in the roots $(64.5 \%)$.

The authors concluded that the period of the greatest demand for the most macronutrients in beetroot plant transplanted is from 29 to 43 DAT and that the decreasing order of exported macronutrients in the roots is $\mathrm{K}>\mathrm{N}>\mathrm{P}>\mathrm{Mg}>\mathrm{S}>\mathrm{Ca}$ and in plant (aboveground part + root) is $\mathrm{K}>\mathrm{N}>\mathrm{Mg}>\mathrm{Ca}>\mathrm{P}>\mathrm{S}$.

\section{ACKNOWLEDGEMENT}

The authors thank CAPES and $\mathrm{CNPq}$ for the scholarships granted.

\section{REFERENCES}

ALVES, AU; PRADO, RM; GONDIM, ARO; 
FONSECA, IM; CECÍLIO FILHO, AB. 2008. Desenvolvimento e estado nutricional da beterraba em função da omissão de nutrientes. Horticultura Brasileira 26: 292-295.

CARDOSO, AII. 2013. Produtores apostam em beterrabas híbridas. Revista Campo \& Negócios 45: 14-16.

CUNHA, AR; MARTINS, D. 2009. Classificação climática para os municípios de Botucatu e São Manuel, SP. Irriga 14: 1-11.

FERNANDES, AM; SORATTO, RP; SILVA, BL. 2011. Extração e exportação em cultivares de batata: I - macronutrientes. Revista Brasileira de Ciência do Solo: 36: 2039-2056.

FONSECA, AS; CARRIBEIRO, LS; SOUZA, TR; FORATTO, LC; VILLAS BOAS, RL. 2009. A técnica de fertirrigação.. In: SALOMÃO, LC; SANCHES, LVC; SAAD, JCC; VILLAS BOAS, RL (org). Manejo da irrigação: um guia prático para o uso racional da água. Botucatu: FCA/FEPAF, v. VI, p.87-114.

FURLANI, PR; PURQUERIO, LFV. 2010. Avanços e desafios na nutrição de hortaliças.
In: PRADO, RM. Nutrição de plantas: diagnose foliar em hortaliças. Jaboticabal: FCAV/CAPES/FUNDUNESP. p.45-62.

GRANGEIRO, LC; NEGREIROS, MZ; SOUZA, BS; AZEVÊDO, PE; OLIVEIRA, SL; MEDEIROS, MA. 2007. Acúmulo e exportação de nutrientes em beterraba. Ciência e Agrotecnologia 31: 267-273.

GUIMARÃES, VF; ECHER, MM; MINAMI, K. 2002. Métodos de produção de mudas, distribuição de matéria seca e produtividade de plantas de beterraba. Horticultura Brasileira 20: 505-509.

HAAG, HP; MINAMI, K. 1987. Nutrição mineral de hortaliças: LXIII. Requerimento de nutrientes pela cultura da beterraba. Anais da Escola Superior de Agricultura "Luiz de Queiroz" 44: 401-407.

KANO, C; CARDOSO, AII; VILLAS BÔAS, RL. 2011. Acúmulo de nutrientes pela alface destinada à produção de sementes. Horticultura Brasileira 29: 70-77.

MALAVOLTA, E. 2006. Manual de nutrição mineral de plantas. São Paulo: Agronômica Ceres. 638p.

MALAVOLTA, E; VITTI, GC; OLIVEIRA, SA. 1997. Avaliação do estado nutricional das plantas, princípios e aplicações. Piracicaba: Potafós. 319p.

NUNES, MA; DIAS, MA; GASPAR, AM; OLIVEIRA, MD; PINTO, E; CARAPAU, AL. 1981. Análise de crescimento da beterraba sacarina em cultura de primavera. Agricultura Lusitana 40: 217-240.

SEDIYAMA, MAN; SANTOS, MR; VIDIGAL, SM. 2011. Produtividade e exportação de nutrientes em beterraba cultivada com cobertura morta e adubação orgânica. Revista Brasileira de Engenharia Agrícola e Ambiental 15: 883-889.

TRANI, PE; RAIJ, B. 1997. Hortaliças. In: RAIJ, B (ed). Recomendações de adubação e calagem para o Estado de São Paulo. 2. ed. Campinas: Instituto Agronômico \& Fundação IAC. 285 p. 